\title{
Assessment of mineral fibres from human lung tissue
}

\author{
JMG DAVIS, B GYLSETH, A MORGAN \\ From the Institute of Occupational Medicine, Edinburgh; the Institute of Occupational Health, Oslo; and the \\ Environmental and Medical Sciences Division, Atomic Energy Research Establishment, Harwell
}

Since the discovery that the inhalation of asbestos fibres could cause pulmonary disease attempts have been made to relate the level of lung damage found at necropsy to the lung fibre burden. At first, studies of asbestos fibres and bodies from lung tissue were qualitative $^{12}$; later the first attempts at quantification used estimations of fibre mass. ${ }^{3}$ For many years studies of lung fibre burden have been based on the counting of fibres by increasingly sophisticated techniques but the published results have not been directly comparable in many cases, and from the few interlaboratory comparisons that have been undertaken it has become obvious that large variations in counts may be produced from the same lung. At present counts of asbestos fibres from lung tissue are becoming very important in medicolegal cases all over the world, often without appreciation of their limitations. For this reason an international workshop was held in Oxford, from 17 to 19 September 1984, to discuss all technical problems related to the estimation of the content of mineral fibres in lung tissue and to determine what could be done to make results from different laboratories more directly comparable. This paper summarises the main points of discussion and the conclusions reached. A list of workshop participants is given at the end.

\section{Sampling of tissue}

The problems encountered in producing a fibre count that is representative of any lung begin at necropsy with the selection of tissue samples for analysis. Blocks of tissue taken only centimetres apart may produce fibre counts that vary by an order of magnitude ${ }^{4-9}$ Recently this variation has been examined systematically in a small series of cases where blocks were taken all round the pleural surfaces. ${ }^{610}$ It was

Address for reprint requests: Dr JMG Davis, Pathology Branch, Institute of Occupational Medicine, Edinburgh EH8 9SU.

Accepted 9 December 1985 found that the tissue sites with the minimum fibre content were the apex and entrance of the oblique fissure in the upper lobe and the costophrenic angle and entrance to the oblique fissure in the lower lobe. The location of these sites suggests that variations in fibre count may be to some extent due to ventilation differences. Where a single fibre count is required from any case for medicolegal or epidemiological purposes, it is suggested that the best compromise is to take several tissue blocks from the peripheral and central regions (avoiding major airways) of both upper and lower lobes and to process these together to produce a single dust suspension for counting and analysis. It has been pointed out that, if a pathologist examines several lungs on the same table, fluid from a lung with a high dust content may contaminate tissue from lungs with few fibres and produce serious errors in fibre count. On some occasions a fibre count is required when only small pieces of tissue from paraffin blocks or biopsy specimens are available. In these cases the likely errors should be explained when results are presented.

\section{Tissue digestion and fibre extraction}

A wide range of methods has been used in different laboratories for the extraction of fibres and asbestos bodies from lung tissue. These include the digestion of tissue by potassium and sodium hydroxide, hydrochloric acid, sodium hypochlorite, hydrogen peroxide, formamide, or enzymes such as papain. ${ }^{11-24}$ In addition, some laboratories have ashed tissues, occasionally at high temperatures but mostly at low temperatures in nascent oxygen. ${ }^{25-31}$ Some of these techniques on their own apparently do not produce a dust suspension sufficiently free of tissue debris for accurate counting, at least by electron microscopy, and a combination of chemical treatments may be necessary. ${ }^{32}$ Some laboratories use low temperature ashing to clean up the specimens after the bulk of tissue has been destroyed by some form of chemical digestion. Even with this technique, however, fibre 
preparations may be contaminated with tissue ash containing deposits of iron, calcium, sodium, potassium salts, and phosphates and these may have to be removed by washing the samples in dilute acid. There are many pitfalls in the handling of extracted dust preparations; appreciable losses of fibres may occur during centrifugation and filtration and some fibres, especially chrysotile asbestos, adhere to glass surfaces. ${ }^{33-37}$ Long term storage or transportation of liquid suspensions of fibre is undesirable as biological contamination may make the preparation unusable. ${ }^{33-35}$ Many laboratories use ether to defat lung tissue before or after digestions or ashing. Some claim that appreciable fibre losses may occur in the ether phase but this point is disputed. ${ }^{17}{ }^{2738} \mathrm{It}$ is also claimed that the sonication of lung dust specimens to disperse suspensions results in the breaking of fibres, but in general this is not considered a serious hazard if the energy used is carefully controlled. A level of $0.5 \mathrm{~W} / \mathrm{cm}^{3}$ for 30 minutes is claimed to have no effect on fibres and this length of time is not necessary for fibre dispersion. ${ }^{27}{ }^{39}$ Some workers suggest, however, that this treatment may cause the separation of chrysotile fibres into individual fibrils; sonication certainly appears undesirable when it is proposed to produce counts of ferruginous bodies, since it is claimed that even mild treatment may remove the body coating. There is a great risk that lung dust specimens may be contaminated by fibre containing reagents or apparatus, and to detect this occurrence blanks should be included with each batch of tissue samples. ${ }^{40}$ There is a particular risk that formalin or paraffin wax (often used more than once) may be heavily contaminated with asbestos fibres and new glassware should always be washed in acid before use with tissue extracts.

It is accepted that the use of low temperature plasma ashing normally produces higher fibre counts than chemical digestion of tissues alone. ${ }^{27}$ It has been suggested that this is due to the breakage of fibres during the ashing process; but it is also claimed that ashed specimens have much less debris and because it is possible to see more fibres, especially the smaller ones, the high counts are in fact the more accurate. ${ }^{82}$ Possibly also no extraction technique is capable of recovering and displaying for counting all the fibres originally present in lung tissue and all counts may be to some extent underestimates.

\section{Counting methods and procedures}

After the extraction of the mineral content of lung tissue the lung fibre burden may be estimated by either phase contrast light microscopy, scanning electron microscopy, or transmission electron microscopy. Most counts are prepared by pathologists who count the fibres in wet preparations by light microscopy using the Fuchs Rosenthal counting chamber. ${ }^{1124}$ This is done because of the simplicity and availability of the method, although it does have accepted disadvantages. Superior preparations for light microscope counting are produced by filtering dust preparations on to Millipore filters, which can be cleared and mounted on glass slides. Not only does this technique provide permanent preparations that can be re-examined as required, but the improved resolution that is achieved is known to result in counts five times higher than those from wet preparations.. ${ }^{41}$ Phase contrast microscopy is used for light microscope counts in most cases, but differential interference microscopy has been advocated as producing a three dimensional image, which some microscopists prefer. $^{8}$

For scanning electron microscopy dust samples are filtered on to Nuclepore filters, which are mounted directly on scanning electron microscopy specimen stubs and examined either uncounted or after being coated with carbon or gold. ${ }^{21262742-46}$ Nuclepore filter preparations are also used by most laboratories in conjunction with transmission electron microscopy. In this case the filters are carbon coated before the plastic of the filter is dissolved by chloroform either by the Jaffe wick technique or under slight vacuum aspiration. ${ }^{3547}$ The filtered dust remains attached to the carbon membrane and this can be mounted on normal transmission electron microscopy grids for counting. Some laboratories do not use filter preparations for transmission electron microscopy counting but deposit dust suspensions directly on to Formvar membranes on transmission electron microscopy grids. The choice of pore diameters for the filters used in fibre counts is important. While there is little fibre penetration of Millipore filters, penetration occurs more easily with Nuclepore filters. For these a pore diameter of $0.2 \mu \mathrm{m}$ is recommended. ${ }^{84849}$ Batches of filters would appear to behave differently. Some have hydrophobic areas that make filtration difficult and affect the even distribution of dust, although it is claimed that this problem may be avoided if filters are previously carbon coated and then wetted with an alcoholic solution. Other filters differ in their solubility in chloroform. Filter batches may also be contamined with asbestos fibres from unknown sources and blank filters must be counted with all batches of tissue preparations to eliminate errors from this source. 5051 Where data from lung tissue analysis are presented, the analytical sensitivity and detection limits should always be given. Most microscopists count and estimate the size of fibres directly from the microscope images produced by light or electron microscopy. Some electron microscopists, however, have adopted 
the procedure of photographing the dust preparations and counting and sizing from the photographic prints (A Langer, personal communication). This technique has advantages in that fibres can be considerable and there is no tendency to count any fibre twice, but it is more time consuming.

Many counting problems with all types of microscopy related to the fibre density in the preparations examined. If fibre density is too great, there is a tendency for microscopists to miss some fibres and produce low counts. The recommended densities are 3-5 fibres/field with the Walton-Beckett graticule in light microscopy and 10-20 fibres/transmission electron microscopy grid opening or the equivalent area of an scanning electron microscopy stub. ${ }^{52}$ Lung dust preparations, however, have a very variable content of non-fibrous mineral particles and on some occasions an unsatisfactory low density of fibres has to be accepted so that the other dust does not obscure those fibres that are present. Some workers suggest that fibre counting should be undertaken against a constant background density of non-fibrous particles. While some laboratories vary the dilutions of their filtered dust preparations to produce the best compromise preparation for counting and sizing, others do not and count a constant area regardless of the fibre number found. With low density preparations this has disadvantages in that overall counts may be based on the actual finding of a very few fibres. For counting purposes the usual definition of a fibre is that originally suggested by the Asbestosis Research Council in $1961^{53}$ - that is, all mineral particles with an aspect ratio greater than $3: 1$ are considered as fibres even though it is realised that some are elongated plates. This definition has been questioned because fragmentation of non-fibrous minerals often produces particles that fit this definition and also because of evidence that the most dangerous fibres have aspect ratios far greater than $3: 1$. Some have suggested that the critical aspect ratio should be changed to $5: 1$ or even 10:1, which would greatly reduce the numbers of fibres to be counted; but this change is resisted for two reasons. Firstly, the recognition of an aspect ratio greater than $3: 1$ is quite easy for microscopists, but even 5:1 and certainly 10:1 would require all fibres to be measured if they were close to the stated ratio. Secondly a change made at this stage would make it impossible to compare future counts with those accumulated and published in the past.

While the 3:1 aspect ratio appears universal, different laboratories have different lower limits for the length and diameter of fibres included in their counts. This depends to some extent, but not entirely, on the sensitivity of the instrument used.$^{54}$ For this reason, total fibre counts from different laboratories often cannot be compared. While individual laboratories will necessarily retain their established procedures, it is recommended that in future all published work should include as a minimum requirement stardard reference points, such as fibres $>5 \mu \mathrm{m}$ in length, so that comparisons can be made. Not all laboratories estimate fibre size when undertaking dust counts and their results can be misleading where the proportions of very short fibres, now believed to be relatively innocuous, are high. This problem would be eliminated by at least classifying fibres into lengths of $<5$ and $\geqslant 5 \mu \mathrm{m}$. For research purposes at least, fibre sizing is highly desirable. Many laboratories undertake this but express their results as accumulated percentages. Many workers now believe that this is not the best method of data presentation and classification of fibres into size ranges would be more easily interpreted and more valuable. While many workers favour simple arithmetic size ranges it has also been suggested that the boundaries of length categories should be logarithmic, to match the usual length distribution, and should repeat at decade intervals.

\section{Analysis of fibre types}

The main purpose of undertaking fibre counts from human lung tissue is to determine the amount of asbestos present, since this group of minerals has definitely been associated with disease production. Not all types of asbestos, however, are regarded as equally dangerous. ${ }^{55}$ In addition, other types of fibres are now produced and used by industry and many types of minerals occur in a fibrous form in the environment and may be found in human lungs. For these reasons the detailed analysis of a selection of fibres from each lung sample examined is no less important than counts and fibre size distributions of the total fibre burden of the lung. Important information on fibre types is obtained by a combination of polarised light microscopy and dispersion staining light microscopy. ${ }^{5657}$ These techniques, however, are most useful for the examination of bulk mineral samples and, although they could help with the identification of the larger fibres from human lungs, analytical techiques associated with electron microscopy have been preferred. Laboratories using transmission electron microscopy can obtain electron diffraction patterns that permit the specific recognition of many fibre types, ${ }^{225859}$ but the most usual analytical technique at present is energy dispersive $x$ ray analysis, which can be used in conjunction with either transmission ${ }^{59-62}$ or scanning electron microscopy. ${ }^{64-46}$ While the elemental analyses produced by this system may be extremely useful, there are problems that have to be taken in account. 
Chrysotile fibres lose most of their magnesium after a period in lung tissue and even unleached chrysotile varies in its content of contaminating elements, such as nickel and manganese, according to the area in which it was mined. Because of these difficulties, the measurement of the $7.3 \AA$ electron diffraction pattern obtained from chrysotile may be necessary for the definitive recognition of this material. Crocidolite and amosite pose problems of analysis since their electron diffraction patterns are very similar and differentiation by energy dispersive $x$ ray analysis depends mainly on the presence of a small manganese peak (with amosite) or a small sodium peak (with crocidolite) that are not always easily discerned. In many instances positive recognition of a fibre may not be possible; but in this case it may be possible to determine whether the fibre is asbestos or not, and this information is important.

\section{Relation between lung fibre burden and disease}

Considerable effort is expended on the counting and recognition of mineral fibres from human lungs in order to relate this information to the occurrence and severity of disease, but there is concern over the way that data are often presented. Fibre counts are usually expressed as a number of fibres per gram of dried lung tissue; but the proportion of solid tissue in any lung specimen varies considerably with disease, especially where advanced fibrosis is present. For this reason, counts of fibres from badly diseased lungs may appear lower than in lungs with little fibrosis, even when the total number of fibres in the lung is the same. This probably explains an apparent anomaly in the relationships between fibre and disease. While the lower lobes of the lungs generally have higher levels of asbestosis ${ }^{63}$ many workers have reported higher fibre counts in the upper lobes. ${ }^{722}$ This problem is not easily solved. It has been suggested that results should be expressed in relation to a fixed volume of lung tissue rather than to dry weight; but for this approach carefully controlled inflation of all lungs would be necessary - and in any case various disease states, especially fibrosis, can cause contraction of part of the lung.

Interpretations of lung fibre counts are further complicated and confused by changes in lung fibre burden that occur during life. Large amounts of deposited fibres of all types are certainly cleared from lung tissue in the course of several years, whether by physical removal or chemical disolution - especially in the case of chrysotile asbestos. There are many reports of workers exposed mainly to chrysotile during life who are found to have much more amphibole asbestos (crocidolite amosite, tremolite) than chrysotile in their lungs at necropsy. ${ }^{2862}$ One possibly very important example of this was found in Canadian chrysotile miners ${ }^{5961}$ where most of the dust found at necropsy was tremolite, present in the original ore in small percentages as a contaminant. Pure tremolite has been reported from experimental studies to be very pathogenic ${ }^{6465}$ and perhaps chrysotile ore containing this material should be used with particular caution.

The removal of chrysotile from lung tissue with time makes it very difficult to relate chrysotile counts to disease and several publications have reported that chrysotile levels in diseased individuals and controls are similar. ${ }^{3066-68}$ There is a suggestion that chrysotile fibres in the lungs of industrially exposed individuals are longer than in those exposed to chrysotile in the general environment, ${ }^{6970}$ but this has not been related to degrees of pulmonary disease.

Lung asbestos counts which, as explained, relate mainly to amphibole fibres do appear to be correlated with degrees of pulmonary fibrosis (asbestosis), but there are wide variations in the actual figures. ${ }^{112471}$ In some countries it is accepted that bronchial carcinoma should be considered to result from asbestos exposure only if asbestosis is also present, so that in such cases the lungs would always have relatively high dust levels. ${ }^{72}$ This does not, however, apply to mesotheliomas. While lung fibre counts in some cases with industrial exposure can be extremely high and there is evidence of a dose relationship in humans as well as experimental animals, ${ }^{7374}$ some cases of mesothelioma have counts that are within the range found in the lungs of the normal urban population. ${ }^{7677}$ Where this occurs there is now some evidence that the length of fibres (not necessarily asbestos) in individuals who develop mesothelioma is higher than in other people. ${ }^{78}$ In industrially exposed populations the lungs from patients with mesothelioma tend to have higher counts of amphibole fibres than those from individuals who do not develop this disease, but figures for chrysotile are similar for the two groups. ${ }^{626668}$ While this finding probably relates to the dissolution of chrysotile within the lung tissue, extremely few mesotheliomas have been reported in workers exposed only to chrysotile, and we must now consider whether these few were caused by tremolite contamination of the chrysotile ore. ${ }^{79}$ Perhaps it is not surprising that correlation between dust counts and mesothelioma is poor since it is likely to be the portion of the lung dust burden that reaches the pleural surface that really matters. So far, no information is available on whether this differs with individuals either in the mass of dust moved or in the proportions of fibres of dangerious lengths. The suggestion of Stanton his classic paper ${ }^{80}$ that the most dangerous fibres are those over $8 \mu \mathrm{m}$ in length and under $1.5 \mu \mathrm{m}$ in diameter appears to hold good, although informa- 
tion on the relationship between fibre length and disease is being refined. ${ }^{81}$ It has been reported that amosite fibres need to be longer to produce pulmonary fibrosis and pulmonary tumours in experimental animals than to produce mesotheliomas after injection. ${ }^{82}$ Further, amosite and erionite fibres over $5 \mu \mathrm{m}$ in length produce few if any mesotheliomas after injection $^{82}$ (also JC Wagner, personal communication), but some tumours have been reported after the injection of a chrysotile sample where most of the fibres were under $5 \mu \mathrm{m}$ in length. ${ }^{83} 84$ The relationship between exposure to mineral fibres and the development of mesothelioma is discussed in an editorial article in this issue (p81).

\section{Asbestos or ferruginous bodies}

The relationship of asbestos bodies to pulmonary disease and therefore the importance of counting asbestos bodies extracted from lung tissue are still under discussion. The lungs of most subjects with asbestosis do have sufficient bodies for them to be found during routine histological examination and these are useful aids to diagnosis. In occasional patients with pulmonary fibrosis, however, asbestos bodies cannot be found, even after exhaustive light microscopic examination of tissue, although subsequent electron microscopic examination of extracted lung dust produces extremely high fibre counts. ${ }^{69}$ Many years ago it was suggested that the coating of asbestos fibres protected the lung tissue from the harmful effect of the dust, ${ }^{85}$ and some still claim that the highest asbestos body counts are found in cases with no fibrosis. It has been reported that the proportion of fibres that are coated may be relatively constant and that asbestos body counts are related to fibre counts, at least with light microscopy. This does not appear to be universally true, however. ${ }^{17}$ Only a small proportion of the total fibre burden of the lung ever becomes coated, probably no more than $1 \%$; but the proportion increases with fibre length and for some amphibole types it is claimed that all fibres over $80 \mu \mathrm{m}$ in length become coated. ${ }^{17}$ In human lungs most of the asbestos bodies extracted can be shown to have formed around amphibole fibres, ${ }^{4586-88}$ and this has led to suggestions that the coating of chrysotile fibres is rare and that asbestos bodies will not be useful in the diagnosis of asbestos related disease if only chrysotile exposure has occurred. Chrysotile fibres readily become coated in some species of experimental animals $^{89}$ and can be detected in this form in the lungs of chrysotile miners. ${ }^{90}$ The paucity of coated chrysotile fibres in most human lungs therefore probably relates to the break up and dissolution of chrysotile fibres in general; it has even been claimed that coated chrysotile fibres are more subject to chem- ical dissolution than uncoated ones. ${ }^{91}$ If counts of asbestos bodies are to be undertaken, it is important to remember that after some extraction techniques, notably ashing, the asbestos body coating may be extremely fragile and easily removed by sonication.

\section{Interlaboratory counting variation}

Over many years techniques for the counting of asbestos fibres from airborne samples have been gradually refined. A standard method for light microscopy has been available for some time and is now in widespread use, ${ }^{92}$ and there has been good progress on the standardisation of counting methods for use with scanning electron microscopy. ${ }^{93}$ Nevertheless, different counters in one laboratory and particularly counters in different laboratories are known to be capable of producing widely differing results, and much effort has been expended to improve this situation. In Britain an informal light microscope comparison has developed into an official scheme sponsored by the Health and Safety Executive (HSE) for the categorisation of laboratories carrying out asbestos counting. ${ }^{94}$ Satisfactory performance in this scheme is a requisite for laboratories seeking accreditation from the national testing laboratory accreditation scheme (Natlas). ${ }^{95}$ Informal international comparisons are also in progress. An international comparison of laboratories counting man made mineral fibres has used both light and scanning electron microscopy. ${ }^{96}$ For all these schemes two to four-fold differences have been found between competent laboratories counting standard specimens. Continued circulation of specimens can reduce the range of count somewhat but it is accepted that variations in counts will continue to occur. This means that the main value of interlaboratory comparisons will always be to quantify and minimise variability rather than to eliminate it. So far there has been little attempt to correlate figures for lung fibre content produced by different laboratories, although there have been some small scale comparisons between workers using similar techniques that are encouraging. ${ }^{97}$ In a recent exercise seven laboratories extracted and counted fibres from the lungs of six individuals exposed to asbestos, ${ }^{98}$ using techniques that included both light microscopy and scanning and transmission electron microscopy. While the ability of different laboratories to recognise cases with high or low fibre levels was good, correlation between the actual counts was poor, even between laboratories using similar techniques. Thus laboratories may be internally consistent in their results but at present apparently comparisons between the counts from different laboratories are dangerous.

It has been recommended that to improve the accuracy of counting an international counting trial, simi- 
lar to that in progress for airborne dust, ${ }^{94}$ should be set up and standard specimens should be circulated for counting. This scheme will be organised from Edinburgh and will take place in three stages. At first, artificial samples prepared from pure asbestos will be circulated to explore the intrinsic problems of fibre counting per se. These will be followed by lung dust extracts to study the problems of fibre counting against a background of non-fibrous material. Finally, homogenates of lung tissue will be circulated so that variations associated with the tissue digestion process can be examined. Samples for light microscopy counting will be circulated as cleared and permanently mounted millipore filters, while for electron microscopy Nuclepore filters will be circulated, either uncoated or already carbon coated. A tissue homogenate is preferred for trials of digestion techniques since, although homogenisation may reduce the mean fibre length, it is hoped that the material supplied to different laboratories will have a uniform fibre content. In the first instance primate lungs experimentally exposed to asbestos will be homogenised, human lung homogenates being examined later. It is hoped that the initial set of trials will enable problem areas to be identified, but small circulation of specimens may be continued on a long term basis to provide a continual reference of interlaboratory counting variations.

This workshop was sponsored by the North Atlantic Treaty Organisation and the British Asbestosis Research Council.

The following scientists took part in the Workshop on the Assessment of Mineral Fibres from Human Lung Tissue

Dr JL Abraham; Mr J Addison; Drs T Ashcroft, RE Bolton, L Le Bouffant, K Browne, EJ Chatfield, A Churg, JE Craighead, N Crawford; Professor JCA Davies; Drs JMG Davis, RF Dodson, F Eitner, KH Friedrichs, A Gaudichet, T Goffe, F Green; Mr M Griffith; Drs D Groth, B Gylseth, G Harlow; Mr A Holmes; Mr R Hunt; Drs N Johnson, JSP Jones, M Kimball (representing Dr A Langer), Lacquet, A Marconi, H Marfels; Mr R Mitha (representing Dr F Pooley); Drs G Monchaux, A Morgan, G Mowe, U Nebe, $K$ Olbricht; Professor H Otto; Drs K Robock, A Rogers, V Roggli, VA Ruckley, T Schneider, P Sebastien, V Skaug, GK Sluis-Cremer, L Swinburne, J Tucker, JC Wagner, $P$ van der Wal; Professor I Webster; Drs F Whitwell, K Yokoyama.

\section{References}

1 Beger PJ. Uber die Asbestosiskorpherchen. Virchows Arch (Pathol Anat) 1933;200:280-353.

2 Gloyne SR. The asbestosis body. Lancet 1932;ii:1351-5.

$3 \mathrm{Knox}$ JF, Beattie J. Mineral content of the lungs after exposure to asbestos dust. Arch Environ Health 1954;10:23-9.

4 Churg A, Wood P. Observations on the distribution of asbestos fibres in human lungs. Environ Res 1983;31:374-80.

5 Dodson RF, Greenberg SD, Williams MG, Corn CJ, O'Sullivan MF, Hurst GA. Asbestos content in lungs of occupationally and non occupationally exposed individuals. JAMA 1984;252:68-71

6 Morgan A, Holmes A. Distribution and characteristics of amphibole asbestos fibres, measured with the light microscope, in the left lung of an insulation worker. $B r J$ Ind Med 1983;40:45-50.

7 Ophus EM, Mowe G, Gylseth B. Scanning Electron Microscopy and $\mathrm{x}$-ray microanalysis of mineral deposits in lungs of a patient with malignant mesothelioma $\mathrm{Br} J$ Ind Med 1980;37:375-81.

8 Rogers AJ. Determination of mineral fibre in human lung tissue by light microscopy and transmission electron microscopy. Ann Occup Hyg 1984;28:1-12.

9 Roggli VL, Pratt PC. Numbers of asbestos bodies on iron-stained tissue sections in relation to asbestos body counts in lung tissue digests. Hum Pathol 1983; 14:355-61.

10 Morgan A, Holmes A. Distribution and characteristics of asbestos fibres in the lungs of Finnish anthophyllite mine-workers. Environ Res 1984;33:62-75.

11 Ashcroft T, Heppleston AG. The optical and electron microscopic determination of pulmonary asbestos fibre concentration and its relation to human pathology reaction. J Clin Pathol 1973;26:224-34.

12 Eitner F, Otto H. Zur Dignität von Asbestokörperchenzahlungen im Lungengewebe. Arbeitsmedizin Sozialmedizin Präventivmedizin 1984;19:1-5.

13 Friedrichs KH, Otto H. Fibers in human lung dust samples: a scanning electron microscope study. Am Ind Hyg Assoc J 1981;42:150-6.

14 Gold C. The quantitation of asbestosis in tissue. In: The association of clinical pathologists: 80th general meeting. J Clin Pathol 1968;21:537.

15 Gross P, Cralley LJ, Davis JMG, De Treville RTP, Tuma J. A quantitative study of fibrous dust in the lungs of city dwellers. In: Walton WH, ed. Inhaled Particles III. Woking: Unwin, 1971:671-9.

16 Morgan A, Talbot RJ, Holmes A. Significance of fibre length in the clearance of asbestos fibres from the lung. $\mathrm{Br} J$ Ind Med 1978;35:146-53.

17 Morgan A, Holmes A. Concentrations and dimensions of coated and uncoated asbestos fibres in the human lung. Br J Ind Med 1980;37:25-32.

18 Otto $\mathrm{H}$. Das berufsbedingte Mesotheliom in der BRD. Der Pathologe 1980;2:8-18.

19 Pooley FD, Oldham PD, Chang-Hyun UM, Wagner JC. The detection of asbestos in tissues. In: Shapiro HA, ed. Pneumoconiosis. Proceedings of the International Conference, Johannesburg. Cape Town: Oxford Unviersity Press, 1970:108-16.

20 Rivers D, Morris TG, Wise ME. The fibrogenicity of some respirable dusts measured in mice. $\mathrm{Br} \cdot \mathrm{J}$ Ind $\mathrm{Med}$ 1963;20:13-23.

21 Roggli VL, Shelburne JD. New concepts in the diagnosis of mineral pneumoconiosis. Sem Respir Med 1982;4:138-48.

22 Sebastien P, Fondimare A, Bignon J, Monchaux G, Desbordes J, Bonnaud G. Topographic distribution in relation to occupational and non-occupational exposure. In: Walton WH, ed. Inhaled particles IV. Oxford: Pergamon Press, 1977:435-46. 
23 Smith MJ, Naylor B. A method for extracing ferryginous bodies from sputum and pulmonary tissue. Am J Clin Pathol 1972;58:250-2.

24 Whitwell F, Scott J, Grimshaw M. Relationship between occupations and asbestos fibre content of the lungs in patients with pleural mesothelioma lung cancer and other disease. Thorax 1977;32:377-86.

25 Le Bouffant $\mathrm{L}$. Investigation and analysis of asbestos fibres and accompanying minerals in biological materials. Environ Health Perspect 1974;9:149-54.

26 Gylseth B, Ophus EM, Mowe G. Determination of inorganic fibre density in human lung tissue by scanning electron microscopy after low temperature ashing. Scand J Work Environ Health 1979;5:151-7.

27 Gylseth B, Baunan RH, Bruun R. Analysis of inorganic fibres in biological samples by scanning electron microscopy. Scand J Work Environ Health 1981;7:101-8.

28 Manke J, Brückel B, Rödelspergeer K, Woitowitz H-J. Lungenstaubanalyse nach beruflicher Gefährdung durch Wei $\beta$-asbest (Chrysotil). Arbeitsmedizin Sozialmedizin Präventivmedizin 1984;11:267-61.

29 Manke J, Rödelspergeer K, Brückel B, Woitowitz H-J. Test of a plasma ashing method for STEM fibre analysis in human lung tissue. In: Proceedings of XXI International Congress on Occupational Health, 9-14 September 1984, Dublin. (in press).

30 Rödelsperger K, Woitowitz H-J. Manke J, Brückel B, Giesen T. Die portmortale Lungenstaubanalyse als Beweismittel einer beruflichen Asbeststaubgefährdung. Zentralblatt für Arbeitsmedizin 1985;35:10-7.

31 Stokin I, Rüttner JR, Sahu AP, Schibli L, Spycher MA. Elektronemikroskopische Bestimmung von Zahl und Grøssenverteilung von mineralischen Fasern in asbestexponierten und nicht asbestexponiereten Lungen. Staub Reinhaltung der Luft 1981;41:188-222.

32 Williams MG, Dodson RF, Corn C, Hurst GA. A procedure for the isolation of amosite asbestos and ferruginous bodies from lung tissue and sputum. $J$ Toxicol Environ Health 1982;10:627-38.

33 Chatfield EJ. Analytical procedures and standardisation for asbestos fibre counting in air, water and solid samples. (Proceedings of the NBS/EPA Asbestos Standards Workshop 1980.) Washington: National Bureau of Standards, 1982:91-107. (NBS Special Publication 619.)

34 Chatfield EJ, Dillon MJ, Stott WR. Development of improved analytical techniques for determination of asbestos in water samples. US EPA contract no 68-03-2717. Available from National Technical Information Service, 5285 Port Royal Road, Springfield, VA22161 (order No PB 83-261-651).

35 Chatfield EJ. Determination of asbestos fibre in air and water. Missisauga, Ontario: Ontario Research Foundation, 1984. (Document N-14.)

36 Gylseth B, Baunan RH, Overaae L. Analysis of fibres in human lung tissue. $\mathrm{Br} J$ Ind Med 1982;39:191-5.

37 Johnson NF, Lincoln JL, Willis HA. Analysis of fibres recovered from lung tissue. Lung 1984;162:37-49.

38 Melton CW, Anderson SJ, Dye CF, Chase WE, Heffelfinger RE. Development of a rapid analytical method for determining asbestos in water. Athens, Georgia: US Environmental Protection Agency, Environmental Research Laboratory, 1978.

39 Spurny KR, Støber W, Opiela H, Weiss G. On the problem of milling and ultrasonic treatment of asbestos and glass fibres in biological and analytical applications. $\mathrm{Am}$ Ind Hyg Assoc J 1980;41:198-203.
40 Marconi A, Cecchetti G, Barbieri M, Bontempelli E. Fibrous particulate contamination of some liquids often used in asbestos sample analysis. In: Proceedings of 5th AIA Colloquium on Dust Measurement Techniques and Strategy, Johannesburg. London: Asbestos Information Association, 1984:318-27.

41 Morgan A, Holmes A. Concentrations and characteristics of amphibole fibres in the lungs of workers exposed to crocidolite in the British gas-mask factories, and elsewhere, during the second world war. Br J Ind Med 1982;39:62-9.

42 Abraham JL, Smith CM, Burnett BR. Changes in lung chrysotile asbestos burden during and following six weeks exposure in rats [abstract]. Lab Invest 1984;50:1 A.

43 Chatfield EJ. Identification and measurement of asbestos fibres by electron microscopy: parts I and II. Asbestos 1978;59(8):4-13; 59(9):6-12.

44 Chatfield EJ, Dillon MJ. Some aspects of specimen preparation and limitations of precision in particulate analysis by SEM and TEM. Scanning Electron Microscopy 1978;i:487-96.

45 Roggli VL, McGavran MH, Subach J, Sybers HD, Greenberg SD. Pulmonary asbestos body counts and electron probe analysis of asbestos body cores in patients with mesothelioma. Cancer 1982;50:2423-32.

46 Roggli VL. Scanning electron microscopic analysis of mineral fibres in human lungs. In: Shelburne JD, Ingram $\mathrm{P}$, eds. Microprobe analysis in medicine. Washington DC: Hemisphere Publishing Corporation (in press)

47 Sebastien P, Billon MA, Janson X, Bonnaud G, Bignon J. Utilisation du microscope electronique a transmission (MET) pour la mesure des contaminations par l'amiante. Arch Mal Prof 1978;29:229-48.

48 Boatman ES et al. Quantitative analysis of urine to assess exposure to asbestos fibres in drinking water in the Puget Sound region. Environ Health Perspect 1983;53:131-9.

49 Spurny K, Weiss G, Opiela H. Zur Filtration von faserigen Partikeln. Staub Reinhalturg der Luft 1985; 45:106-11.

50 Ranson D, Pooley FD. [Discussion summary.] In: Wagner JC, ed. Biological effects of mineral fibres. Vol 1. Inserm Symposia Series 1980;92:377-81, (IARC Scientific Publication 30).

51 Spurny KR, Lodge JP, Frank ER, Sheesley DC. Aerosol filtration by means of nuclepore filters: structural and filtration properties. Environmental Science and Technology 1969;3:453-68.

52 Health and Safety Executive. Asbestos fibres in air. In: Methods for the determination of hazardous substances. Bootle: Health and Safety Executive, 1984. (Obtainable from HMSO.)

53 Asbestosis Research Council. The measurement of airborne dust by the membrane filter method. Rochdale: ARC, 1971. (Technical Note 1.)

54 Rooker SJ, Vaughan MP, Le Guen JM. On the visibility of fibres by phase contrast microscopy. Am Ind Hyg Assoc $J$ 1982;43:505-15.

55 Davis JMG. The pathology of asbestos related disease. Thorax 1984;39:801-8.

56 McCrone WC, Stewart IM. Identification of asbestos by polarised light microscopy. In: The particle atlas. 2 nd ed. (Vol 5 of Light microscopy atlas and techniques.) Ann Arbor: Ann Arbor Science, 1979:1369-79.

57 Monkman LJ. Procedure for the detection and identification of asbestos and cther fibres in fibrous inorganic materials. Ann Occup Hyg 1979;22:127-39. 
58 Churg A. Asbestos fibre content of the lungs in patients with and without asbestos airways disease. Am Rev Respir Dis 1983;127:470-3.

59 Pooley FD. An examination of the fibrous mineral content of asbestos lung tissue from the Canadian chrysotile mining industry. Environ Res 1976;12:281-98.

60 Pooley FD, Clark NJ. Quantitative assessment of inorganic fibrous particulates in dust samples with an analytical transmission electron microscope. Ann Occup Hyg 1979;22:253-71.

61 Rowlands N, Gibbs GW, McDonald AD. Asbestos fibres in the lungs of chrysotile miners and millers. Ann Occup Hyg 1982;26:411-6.

62 Gylseth B, Mowe G, Wannag A. Fibre type and concentration in the lungs of workers in an asbestos cement factory. Br J Ind Med 1983;40:375-9.

63 Craighead JE. Asbestos-associated disease. Arch Pathol Lab Med 1982;106:542-96.

64 Wagner JC, Chamberlain M, Brown RC, Berry G, Pooley FD, Davies R, Griffiths DM. Biological effects of tremolite. Br J Cancer 1982;45:352-60.

65 Davis JMG, Addison J, Bolton RE, Donaldson K, Jones AD, Miller BG. Inhalation studies on the effects of tremolite and brucite dust in rats. Carcinogenesis 1985;6:667-74.

66 Wagner JC, Berry G, Pooley FD. Mesotheliomas and asbestosis type in asbestos textile workers: a study of lung contents. $\mathrm{Br} \mathrm{Med} J$ 1982;285:603-6.

67 Wagner JC, Pooley FD, Berry G, et al. A pathological and mineralogical study of asbestos-related deaths in the United Kingdom in 1977. Ann Occup Hyg 1982;26:423-35.

68 Jones JSP, Pooley FD, Clark NJ, et al. In: Wagner JC, ed. Biological effects of mineral fibres. Vol 1. Inserm Symposia Series 1980;92:187-99. (IARC Scientific Publication No 30.)

69 Churg A. Fibre size of users of processed chrysotile [abstract]. Am Rev Respir Dis 1985;131:A186.

70 Pooley FD. Electron microscope characteristics of inhaled chrysotile asbestos fibre. $\mathrm{Br} J$ Ind $\mathrm{Med}$ 1972;29:146-53.

71 Wagner JC, Pooley FD, Berry G. A pathological and mineralogical study of asbestos related deaths in the United Kingdom in 1977. Ann Occup Hyg 1982;26:423-30.

72 National Insurance (Industrial Injuries) Act 1965: Pneumoconiosis and byssinosis. London: HMSO, 1973:28.

73 Browne K. Asbestos related mesothelioma: epidemiological evidence for asbestos as a promoter. Arch Environ Health 1983;38:261-6.

74 Bolton RE, Davis JMG, Miller B, Donaldson K, Wright A. The effect of dose of asbestosis on mesothelioma production in the laboratory rat. In: Proceedings of VIth International Pneumoconiosis Conference. Bochum: Bergbau Berufsgenossenschaft, 1984:1028-36.

75 Jones JSP, Smith PG, Pooley FD, et al. The consequence of exposure to asbestos dust in a war-time gas-mask factory. In: Wagner JC, ed. Biological effects of mineral fibres. Vol 2. Inserm Symposia Series. 1980;92:637-53. (IARC Scientific Publication No 30.)

76 Gylseth B, Mowe G, Skaug V, Wannag A. Inorganic fibers in lung tissue from patients with pleural plaques or malignant mesothelioma. Scand J Work Environ Health 1981;7:109-13.

77 Mowe G, Gylseth B, Hartveit F, Skaug V. Occupational asbestos exposure, lung-fiber concentration and latency time in malignant mesothelioma. Scand $J$ Work Environ Health 1984;10:293-8.

78 Friedrichs KH, Molik B. Microscopic observations on some fibrous dust samples. Zentralbl Bakteriol (B) (in press).

79 Churg A, Wiggs B, DePaoli L, Kampe B, Stevens B. Lung asbestos content with chrysotile workers with mesothelioma. Am Rev Respir Dis 1984;130:1042-5.

80 Stanton MF. "Some etiological considerations of fibre carcinogenesis". In: Wagner JC, ed. Biological effects of mineral fibres. Vol 1. Inserm Symposia Series 1973;92:289-94. (IARC Scientific Publication No 8.)

81 Friedrichs $\mathrm{KH}$, Otto $\mathrm{H}$. Fibres in human lung dust samples: a scanning electron microscope study. Am Ind Hyg Assoc $J$ 1981;42:150-6.

82 Davis JMG, Addison J, Bolton RE, Donaldson K, Jone $\mathrm{AD}$, Smith T. The pathogenicity of long versus short fibre samples of amosite asbestos administered to rats by inhalation and intraperitoneal injection. Br J Exp Pathol (in press.)

83 Monchaux G, Bignon J, Jaurand MC, et al. Mesotheliomas in rats following innoculation with acidleached chrysotile asbestos and other mineral fibres. Carcinogenesis 1981;ii:229-36.

84 Le Bouffant L, Daniel H, Henin JP, Martin JC. Pouvoir carcinogene des fibres de chrysotile de longuer $<5 \mu \mathrm{m}$. Cahiers de notes documentaires INRS 1985;118:83-9.

85 Beattie J. The asbestos body. In: Davies CN, ed. Inhaled particles and vapours. Oxford: Pergamon Press, 1961:434-41.

86 Churg A, Warnock ML. Analysis of cores of asbestosis bodies from members of the general population. Am Rev Respir Dis 1978;120:781-6.

87 Gylseth B, Baunan RH. Topographic and size distribution of asbestos bodies in exposed human lungs. Scand $J$ Work Environ Health 1981;7:190-5.

88 Dodson RF, Williams MG, Hurst GA. Method for removing the ferruginous coating from asbestos bodies. J Toxicol Environ Health 1983;11, suppl:959-66.

89 Davis JMG. Further observations on the ultrastructure and chemistry of formation of asbestos bodies. Exp Mol Pathol 1970;13, suppl:346-56.

90 Holden J, Churg A. Asbestos bodies and the diagnosis of asbestosis in chrysotile miners. Environ Res (in press).

91 Jaurand MC, Goni J, Jeanrot P, Sebastien P, Bignon J Solubility of chrysotile in vitro in the human lung. Revue francaise des Maladies Respiratoires 1975;4, suppl 2:111-20.

92 European Communities Council Directive of 19.9.83. On the protection of workers from the risks related to exposure to asbestos at work (second individual directive within the meaning of article 8 of directive 80/1 107/EEC 83/477/EEC). Official Journal of the European Commu nities. 1983; L263-25-32.

93 Asbestos International Association. Method for the determination of airborne asbestos fibres and other inorganic fibres by scanning electron microscopy. London Asbestos International Association, 1984. (AIA Health and Safety Publication RTM2.)

94 Crawford NP, Cowie AJ. Quality control of airborne asbestos fibre counts in the United Kingdom. Ann Occup Hyg 1984;28:391-8.

95 NATLAS Executive. NATLAS Information Sheet N1S-11. Teddington: National Physical Laboratory, 1985.

96 The WHO/EURO Technical Committee for monitoring 
and evaluating Man Made Mineral Fibres. The WHO/EURO man made mineral fibre reference scheme. Scand J Work Environ Health 1985;11:123-9.

97 Gaudichet A, Sebastien P, Clark NJ, Pooley FD. Identification and quantification of asbestos fibres in human tissues. In: Wagner JC, ed. Biological effects of mineral fibres. Lyon: International Agency for Research on Cancer, 1980:61-68. (IARC Publication No 30.)

98 Gylseth B, Churg A, Davis JMG, et al. Analysis of asbestos fibres and asbestos bodies in human lung tissue samples. An international interlaboratory trial. Scand $J$ Work Environ Health 1985;11:107-10. 